\title{
KETAHANAN LUNTUR ZAT REAKTIF DAN AZO PADA BAHAN BAKU PRODUK BATIK UNTUK UKM DI JAWA TIMUR
}

\author{
Anik Dwiastuti \\ Endang Prahastuti \\ Esin Sintawati
}

\begin{abstract}
Abstrak: Tujuan penelitian ini menguji ketahanan luntur zat warna tekstilbatik yaitu reaktif dan azo pada uji pencucian menggunakan SNI ISO 105-C06: 2010 dan uji keringat $\mathrm{pH}$ asam dan $\mathrm{pH}$ basa menggunakan SNI ISO 105-E04: 2015 dengan penyesuaian DSTI. Sampel uji untuk zat warna reaktif adalah material katun dan sampel uji azo menggunakan sutera sebagai bahan baku utama untuk produk batik di Jawa Timur. Nilai perubahan warna dan penodaan warna dievaluasi pada konsentrasi larutan yang berbeda sesuai standar uji masing-masing. Hasil penelitian menunjukkan bahwa perbedaan konsentrasi larutan zat reaktif tidak menyebabkan perbedaan yang nyata pada skor perubahan warna dan perbedaan warna katun untuk semua pengujian. Sementara konsentrasi larutan zat azo yang berbeda menyebabkan perbedaan yang nyata pada skor perbedaan warna untuk pengujian sutera.
\end{abstract}

Kata-kata Kunci: reaktif, azo,ketahanan luntur, pencucian, keringat

\begin{abstract}
Colour Fastness Properties of Reactive and Azo Resistance on Batik Dyestuff for Small Enterprises in East Java. The study aims to test reactive and azo dyestuff base on colour fastness of washing based on SNI ISO 105-C06:2010 and perspiration on $\mathrm{pH}$ acid and $\mathrm{pH}$ alcaline based on SNI ISO 105-E04:2015 adjusted with DSTI. The testing sample for reactive substance is cotton and the testing sample for azo is silk, main raw material of batik used in East Java. Colour change and stains are evaluated on different concentrations of the solution according to each standart. The results show that different concentration of reactive solutions do not cause a significant different on colour change and cotton stain for all testing samples. On the other hand, different concentrations of azo solutions cause a significant difference on silk stains.
\end{abstract}

Keywords: reactive, azo, fastness, washing, sweat

$\mathrm{P}$ emerintah mengembangkan industri hilir sektor TPT melalui Rencana Strategis Departemen Perindustrian tahun 2010-2015 dalam bentuk pengelompokan sektor industri kreatif di Indonesia yang diikuti oleh misi pemerintah propinsi
Jawa Timur untuk meningkatkan nilai ekspor produk batik. Namun kenyataanya sebagian besar perajin batik di Jawa Timur masih memiliki kendala dalam hal pemasaran produk batiknya, terutama dalam hal memenuhi pasar ekspor. Humas

Anik Dwiastuti, Endang Pahastuti, dan Esin Sintawati Dosen Jurusan Teknologi Industri Fakultas Teknik Universitas Negeri Malang. Email: anik.dwiastuti.ft@um.ac.id. Alamat Kampus: Jl. Semarang No. 5 Malang 65145. 
Asosiasi Perajin Batik Jawa Timur (APBJT) menyatakan bahwa selama ini permintaan ekspor batik keluar negeri masih terkendala beberapa hal yaitu: (1). tidak ada pedoman kualitas baku, (2). minimnya SDM, dan (3). pembiayaan tidak mencukupi (Pindani, 2015).

Hasil pengamatan di lapangan menunjukkan bahwa beberapa hambatan perajin batik di Jawa Timur dalam memenuhi standar kualitas produk ekspor diantaranya: (1). kurang memahami instrumen terkait standarisasi produk tekstil untuk kebutuhan pasar ekspor, (2). tidak menguasai standarisasi prosess dyeing dan penggunaan dyestuff, (3).tidak melakukan uji baku mutu pada produk yang dihasilkan. Faktor uji baku mutu produk sangat berpengaruh terhadap daya saing global sehingga perlu adanya identifikasi terhadap kualitas bahan baku, dalam hal ini adalah jenis dyestuff yang digunakan oleh UKM batik. Identifikasi kualitas bahan pewarna yang digunakan pada produk batik dapat menjelaskan kualitas dari produk batik itu sendiri, sehingga uji ketahanan luntur warna dapat digunakan untuk melengkapi deskripsi spesifikasi produk sebagaimana yang dipersyaratkan di pasar global. Usaha tersebut diharapkan dapat menjadi daya dorong bagi produk batik Jawa Timur untuk memasuki pasar ekspor.

Evaluasi tekstil merupakan prosedur uji baku mutu pada tekstil dan produk tekstil, yang dibedakan menjadi dua jenis yaitu evaluasi fisika dan evaluasi kimia (Isminingsih, 2013). Pengujian bahan tekstil merupakan bagian dari evaluasi produk yang dilakukan pada sampel kain berfungsi sebagai bentuk pelayanan kepuasan pada konsumen, pemenuhan syarat standarisasi, evaluasi proses dan hasil produksi, pengembangan produk baru, memperjelas spesifikasi produk, dan mencari serta menemukan solusi permasalahan produk.
Salah satu yang menjadi tuntutan standar kualitas untuk produk tekstil di pasar internasional adalah kualitas warna yang dapat dijelaskan dari penilaian ketahanan luntur warna (colour fastness). Atribut colour fastness diantaranya adalah pengukuran color change dan staining test yang mengacu pada standarisasi ISO atau AATCC (Bide, 2012). Zat warna jenis reaktif dan azo adalah dua golongan zat warna impor yang umumnya digunakan oleh UKM di Jawa Timur. Oleh sebab itu, pada penelitian ini pengujian colour fastness dilakukan dengan menggunakan zat warna jenis reaktif dan Azo.

Zat warna reaktif tergolong mudah diabsorbi dan berafinitas baik dengan serat selulosa dan protein. Ditinjau dari sifat kimianya, ada dua golongan zat warna reaktif yang digunakan yaitu reaktif suhu rendah dan reaktif suhu tinggi. Ciri khas zat warna reaktif adalah kemampuannya dalam berikatan dengan serat tekstil untuk membentuk ikatan kovalen antara gugus reaktif dalam dyestuff tersebut dan gugus $-\mathrm{OH},-\mathrm{SH},-\mathrm{NH}_{2}$, dan $-\mathrm{NH}$ yang ada dalam serat.

Azo merupakan kelompok zat warna tekstil berjenis adjektif yang membutuhkan penggunaan elektrolit yaitu garam diazonium sebagai pembangkit warnanya. Jenis zat warna ini dapat diabsorbsi dan berafinitas baik dengan serat sintetis, selulosa maupun wool. Struktur molekul zat warna sintetis golongan azo merupakan kromofor atau gugus pembawa warna yang berhubungan dengan substantifitas, kereaktifan, koefisien difusi, dan kelarutan zat warna yang menentukan corak dan kecerahan warna. Gugus azo memiliki ciri-ciri yaitu senyawanya memiliki paling sedikit satu ikatan $-\mathrm{N}=\mathrm{N}-$. Tiga jenis zat warna golongan azo yaitu mono azo, diazo dan triazo.

Warna adalah salah satu properti yang sangat penting pada sebuah produk. Warna pada produk tekstil warna meru- 
pakan value yang memiliki dampak langsung terhadap tingkat kepuasan penggunanya. Durabilitas atau ketahanan warna pada material tekstil merupakan bagian yang sering diharapkan oleh konsumen sehingga menjadi hal utama dalam proses pengujian warna. Faktor yang berpengaruh langsung terhadap ketahanan warna antara lain struktur molekul proses celup, tipe dan struktur serat material, proses pencelupanya dan kepekatan warna (Cegarra et al., 1992). Fan (2011) menyatakan bahwa identifikasi mengenai golongan zat warna dan bahan kimia yang digunakan pada proses penyempurnaan akhir sebuah kain juga berkaitan dengan analisis terhadap dampak pada lingkungan.

Pengujian ketahanan warna terhadap pencucian dilakukan pada zat reaktif dan azo untuk produksi batik di UKM Jawa Timur karena aktivitas pencucian merupakan perawatan rutin yang dilakukan dalam perawatan pakaian. Lima tipe metode pencucian yang dapat dilakukan yaitu perlakuan saat pencucian, kekentalan cairan sabun, penambahan bakan alkali, dan temperatur pencucian. Meskipun masing-masing metode berbeda, namun standar prosesnya dirancang mendekati sesuai dengan proses pencucian praktis domestik agar hasil uji dapat melengkapi spesifikasi sesuai dengan kebutuhan konsumen. Penentuan konsentrasi larutan merupakan hal yang paling utama pada kelima metode pengujian tersebut karena konsentrasi larutan berpengaruh terhadap perubahan warna dan perbedaan warna (Philip, et.all. 2003). Prinsip pengujiannya adalah proses laundering menggunakan campuran bahan natrium hipoklorit, natrium metasilitat, asam asetat $20,00 \%$ dan sabun netral. Pengaturan suhu secara termostatik dan kecepatan putaran pada alat launderometer memberikan pengaruh tersendiri terhadap hasil pengujian, sehingga pencantuman penggunaan atau pemilihan standar uji yang dilakukan di- perlukan untuk memperjelas spesifikasi produk.

Penilaian ketahanan warna terhadap keringat merupakan sebuah pengujian fisika berkaitan dengan terjadinya perubahan warna dan perbedaan warna pada kain uji yang diberikan perlakuan menggunakan keringat yang memiliki $\mathrm{pH}$ asam dan basa dalam sebuah instrumen yaitu perspiration tester. Campuran natrium khlorida, asam laktat dan zat aditif lainnya yang memiliki $\mathrm{pH}$ 3,5 digunakan untuk membuat artifisial keringat asam. Campuran natrium khlorida, amonium karbonat dan zat aditif lainnya yang memiliki pH 8 digunakan untuk membuat artifisial keringat basa. Perubahan warna pada kain uji dan perbedaan warna dengan kain kontrol dinilai menggunakan grey scale dan staining scale sebagai instrumennya.

Secara umum penilaian ketahanan luntur warna pada kain dapat dilakukan pada berbagai variabel yang mempengaruhinya. Masing-masing ketahanan luntur warna tidak mempunyai korelasi terhadap suatu zat warna tertentu. Oleh sebab itu, sifat tahan luntur warna untuk sebuah zat warna perlu ditentukan sesuai dengan penggunaan akhir dari bahan tekstil tersebut. Pengujian tahan luntur warna akan berbeda sesuai keadaan dan kondisi yang dikehendaki, sehingga untuk menghindari timbulnya penilaian lain maka perlu mencantumkan rujukan standar pengujian yang digunakan.

\section{METODE}

Rancangan penelitian yang digunakan adalah deskriptif kuantitatif dengan tujuan memaparkan kualitas zat reaktif dan azo sebagai bahan baku batik di Jawa Timur menggunakan standar yang berlaku di Indonesia. Pengujian color fastness dilakukan untuk menilai perbedaan warna dan perubahan warna terhadap pencucian. Sampel yang diuji adalah ka- 
tun primissima dengan instrumen launderometer. Pengujian ketahanan luntur warna terhadap keringat $\mathrm{pH}$ asam dan $\mathrm{pH}$ basa dilakukan pada sampel kain sutera menggunakan instrumen perspiration tester.

Konsentrasi larutan yang digunakan berdasarkan dua standar vlot sesuai Dewan Standarisasi Tekstil Indonesia (DSTI), yaitu: (1) zat reaktif dengan komposisi rendah menggunakan vlot 1:10 dan komposisi tinggi menggunakan vlot 1:40, dan (2) zat warna golongan azo menggunakan komposisi vlot 1:20 dan $1: 30$. Penggunaan setiap rasio tersebut menghasilkan konsentrasi larutan yang berbeda.

Zat warna reaktif yang diuji adalah dyestuff jenis reaktif panas, warna merah $27,00 \%$. Uji katun 1 dilakukan pada material katun jenis primissima menggunakan konsentrasi 5,87\%, sedangkan uji katun 2 menggunakan komposisi tinggi dengan konsentrasi 5,38\%. Zat warna kedua yang diuji adalah naphtolat golongan azo (naphtol AS-D) dengan coupling garam diazonium $\mathrm{GG}$ dan merah $\mathrm{R}$ yang diuji pada bahan silk (sutera) pada konsentrasi $4,06 \%$ yang selanjutnya disebut uji sutera 1 dan konsentrasi $4,07 \%$ yang selanjutnya disebut dengan uji sutera 2 .

Metode pengujian ketahanan luntur warna terhadap pencucian menggunakan skala I pada SNI ISO 105-C06:2010, yaitu proses pencucian menggunakan suhu $40^{\circ} \mathrm{C}$, volume larutan $200 \mathrm{ml}$, sabun $0,50 \%$, jumlah kelereng baja 10 , dan lama waktu pencucian 45 menit. Metode skala I ini dipilih karena paling mende-

$\Delta E_{F}=\left[\left(\Delta L^{*}\right)^{2}+\left(\Delta C_{F}\right)^{2}+\left(\Delta H_{F}\right)^{2}\right]^{1 / 2}$

dimana

$$
\begin{aligned}
& \Delta H_{F}=\Delta H_{K} /\left[1+\left(10 C_{M} / 1000\right)^{2}\right] \\
& \Delta C_{F}=\Delta C_{K} /\left[1+\left(20 C_{M} / 1000\right)^{2}\right] \\
& \Delta H_{K}=\Delta H_{a b}^{*}-D \\
& \Delta C_{K}=\Delta C_{a b}^{*}-D \\
& D=\left(\Delta C_{a b}^{*} \cdot C_{M} \cdot e^{-x}\right) / 100
\end{aligned}
$$

kati dengan perlakuan pada pencucian domestik. Perlakuan yang diberikan pada sampel uji menggunakan standar tipe 3, yaitu sampel kain utama berpasangan dengan katun putih sebagai outer-lining pertama dan sutera putih sebagai lining kedua. Sampel uji kain sutera dicuci bersama dengan bahan katun putih sebagai lining pertama dan wool putih sebagai lining kedua. Prosedur pengujiannya yaitu setiap pasangan sampel uji diproses dalam launderometer dengan kecepatan putaran 42/menit. Penilaian hasil perubahan warna dan penodaan warna merujuk pada standar AATCC-TM untuk hasil pencucian, yaitu grey scale dan staining scale 9 skala.

Metode pengujian ketahanan luntur warna terhadap keringat menggunakan standar SNI ISO 105-E04: 2015. Prosedur pengujiannya yaitu sampel kain uji dari bahan katun dipasangkan dengan bahan katun putih sebagai lining pertama dan wool putih sebagai lining kedua. Sampel uji sutera dipasangkan dengan sutera putih sebagai lining pertama dan katun putih sebagai lining kedua. Sampel kemudian direndam dalam larutan keringat artifisial yang bersifat asam dan basa dalam perspiration tester menggunakan tekanan $60 \mathrm{gr} / \mathrm{cm}^{2}$ selama 6 jam.

Penilaian tingkat penyerapan warna serat tekstil menggunakan zat warna reaktif dan azo dinilai menggunakan Scanning Mikroskop Electron (SEM). Formulasi yang digunakan berbasis pada nilai penghitungan $C I E L A B$ Lch. Nilai perbedaan warna dihitung menurut persamaan 1. Nilai M subscript merupakan 
nilai rerata dari kain uji dan kain pembanding.

Parameter tingkatan nilai greyscale untuk color change, dihitung menggunakan persamaan 2 dan persamaan 3. Selanjutnya dilakukan interpolasi dari hasil penghitungan persamaan 2 dan 3 sehingga diperoleh parameter grading sesuai nilai greyscale, seperti pada Tabel 1.

Tabel 1. Greyscale for Staining Step Value

\begin{tabular}{ll}
\hline Calculated $S \boldsymbol{S} \boldsymbol{G}$ & Reported $\boldsymbol{G S S}$ \\
\hline 5.00 to 4.75 & $5-$ \\
4.74 to 4.25 & $4-5$ \\
4.24 to 3.75 & $4-$ \\
3.74 to 3.25 & $3-4$ \\
3.24 to 2.75 & $3-0$ \\
2.74 to 2.25 & $2-3$ \\
2.24 to 1.75 & $2-$ \\
1.74 to 1.25 & $1-2$ \\
Less than 1.25 & $1-0$ \\
\hline
\end{tabular}

(Sumber : Bide, 2012)
Data hasil pengujian adalah nilai perubahan warna dan perbedaan warna akibat pencucian dan keringat yang dievaluasi menggunakan standar greyscale dan staining scale 9 tingkat hasil representasi dari formulasi penghitungan CIELAB. Rentang penilaian dievaluasi berdasarkan perbedaan warna yang terjadi pada kain uji menggunakan representasi spesifikasi colorimeter yang dihitung dari rumus nilai chromatic Adam dalam satuan C.D (color difference) seperti ditunjukkan pada persamaan 4 (Raechel, 2010).

\section{HASIL}

Hasil pengujian menggunakan standar SNI ISO 105-C06:2010 berupa nilai ketahanan luntur warna kain katun dan sutera terhadap pencucian ditunjukkan pada Tabel 2.

$G S_{C}=5-\Delta E_{F} / 1.7$

dimana

$\Delta E_{F} \leq 3.4$

dan

$G S_{C}=5-\log \left(\frac{\Delta E_{F}}{0.85}\right) / \log (2)$

dimana

$\Delta E_{F}>3.4$

$40\left[\left\{0,23 \nabla V_{y}\right\}^{2}+\left\{\nabla\left(V_{x}-V_{y}\right)\right\}^{2}\right]+$

$\left\lceil\left\{0,4 \Delta\left(V_{z}-V_{y}\right)\right\}^{2}\right]^{0,5}$

dimana :

$\mathrm{V}_{\mathrm{x}} \mathrm{V}_{\mathrm{y}}$ dan $\mathrm{V}_{\mathrm{z}}$ merupakan tristimulus $\mathrm{X}, \mathrm{Y}$ dan $\mathrm{Z}$

Tabel 2. Hasil Uji Ketahanan Luntur terhadap Pencucian

\begin{tabular}{lcccc}
\hline Sampel uji & Color Change & $\begin{array}{c}\text { Staining pada } \\
\text { sutera }\end{array}$ & $\begin{array}{c}\text { Staining pada } \\
\text { kapas }\end{array}$ & $\begin{array}{c}\text { Staining pada } \\
\text { wool }\end{array}$ \\
\cline { 2 - 5 } & Nilai GreyScale & \multicolumn{3}{c}{ Nilai StainingScale } \\
\hline Katun 1 & $4-5$ & 4 & 4 & - \\
Katun 2 & $4-5$ & 4 & 4 & - \\
Sutera 1 & 4 & - & 4 & $4-5$ \\
Sutera 2 & 4 & - & 4 & $4-5$ \\
\hline
\end{tabular}


Nilai perubahan warna maupun perbedaan warna pada kain katun dan sutera seperti disajikan pada Tabel 2 menunjukkan hasil yang berbeda untuk masing-masing dyestuff jenis reaktif dan azo. Nilai perubahan warna zat reaktif pada penggunaan konsentrasi $5,87 \%$ yang diuji pada katun melalui pengukuran greyscale berada pada skala 4-5 atau memiliki kategori sedikit lebih baik. Nilai perubahan warna yang dihasilkan pada konsentrasi $5,38 \%$ juga menunjukkan nilai yang sama. Perubahan warna hasil pengukuran staining scale yang terjadi pada pengujian katun terhadap katun dan katun terhadap sutera memiliki nilai penodaan (staining) yang sama yaitu 4 atau dikategorikan baik untuk kedua konsentrasi tersebut.

Perubahan warna zat azo akibat pencucian hasil pengukuran greyscale yang diuji pada bahan sutera dengan konsentrasi larutan $4,06 \%$ menunjukkan nilai pada skala 4 atau dikategorikan sebagai baik. Nilai perbedaan warna hasil pengukuran stainingscale menunjukkan nilai yang berbeda untuk pengujian penodaan (staining) terhadap katun dan wool. Pengujian perbedaan warna sutera dengan konsentrasi $4,06 \%$ hasil pengujian penodaan sutera terhadap katun menunjukkan nilai 4 atau dikategorikan baik dan hasil pengujian sutera terhadap wool nilai penodaannya lebih baik yaitu 4-5 atau dikategorikan sedikit lebih baik.

Pengujian perbedaan warna dengan menggunakan konsentrasi larutan yang berbeda tidak menghasilkan nilai penodaan warna yang berbeda, namun hasil nilai penodaannya tidak sama untuk bahan tekstil yang berbeda jenis seratnya. Hasil ini menunjukkan bahwa kualitas penodaan zat warna azo akan berbeda jika digunakan pada kain dengan jenis serat yang berbeda.

Rentangan nilai toleransi perubahan warna dan penodaan warna uji pencucian untuk zat warna reaktif dan azo dipaparkan pada Tabel 3.

\section{Tabel 3. Nilai Perubahan Warna dan Perbedaan Warna antara Reaktif dan Azo}

\begin{tabular}{lcc}
\hline $\begin{array}{l}\text { Sampel } \\
\text { Uji }\end{array}$ & $\begin{array}{c}\text { Perubahan } \\
\text { warna (C.D) }\end{array}$ & $\begin{array}{c}\text { Penodaan } \\
\text { warna (C.D) }\end{array}$ \\
\hline Katun1 & 0,8 & 4,0 \\
Katun 2 & 0,8 & 4,0 \\
Sutera1 & 1,5 & 2,0 \\
Sutera 2 & 1,5 & 2,0 \\
\hline
\end{tabular}

Pengujian perbedaan warna berdasarkan nilai chromatic Adam menunjukkan nilai yang berbeda. Perubahan warna yang terjadi akibat pencucian pada zat reaktif lebih baik dibandingkan zat azo, dengan nilai 0,80 C.D untuk sampel katun dan 1,50 C.D untuk sutera. Namun untuk penodaan warna, zat azo lebih baik dibandingkan zat reaktif dengan nilai 2,00 C.D untuk sampel sutera dan 8,00 C.D untuk sampel katun.

Hasil pengujian ketahanan luntur warna terhadap keringat menggunakan standar ISO 105-E04:2015 diuraikan pada Tabel 4.

Tabel 4. Hasil Uji Ketahanan Luntur terhadap Keringat

\begin{tabular}{ccccccc}
\hline \multirow{3}{*}{$\begin{array}{c}\text { Sampel } \\
\text { Uji }\end{array}$} & $\begin{array}{c}\text { Color } \\
\text { Change }\end{array}$ & $\begin{array}{c}\text { Staining pada } \\
\text { Sutera/Wool }\end{array}$ & $\begin{array}{c}\text { Staining } \\
\text { pada } \\
\text { kapas }\end{array}$ & $\begin{array}{c}\text { Color } \\
\text { Change }\end{array}$ & $\begin{array}{c}\text { Staining pada } \\
\text { Sutera/Wool }\end{array}$ & $\begin{array}{c}\text { Staining } \\
\text { pada } \\
\text { Kapas }\end{array}$ \\
\cline { 2 - 7 } & $\begin{array}{c}\text { Nilai } \\
\text { GreyScale }\end{array}$ & \multicolumn{2}{c}{ Nilai StainingScale } & $\begin{array}{c}\text { Nilai } \\
\text { GreyScale }\end{array}$ & Nilai StainingScale \\
\hline Katun1 & $4-5$ & $4-5$ & $4-5$ & $4-5$ & $4-5$ & $4-5$ \\
Katun2 & $4-5$ & $4-5$ & $4-5$ & $4-5$ & $4-5$ & $4-5$ \\
Sutera1 & $4-5$ & $3-4$ & $3-4$ & $4-5$ & $3-4$ & $3-4$ \\
Sutera2 & $4-5$ & 4 & 4 & $4-5$ & 4 & 4 \\
\hline
\end{tabular}


Kualitas zat warna reaktif dan azo jika ditinjau dari ketahanan luntur warna terhadap keringat menunjukkan hasil yang berbeda untuk nilai perubahan warna dan perbedaan warna. Nilai perubahan warna zat reaktif menggunakan konsentrasi $5,87 \%$ dan $5,38 \%$ yang ditunjukkan oleh grey scale berada pada skala 4-5 atau dikategorikan sedikit lebih baik untuk semua pengujian ketahanan warna terhadap keringat pada $\mathrm{pH}$ asam maupun $\mathrm{pH}$ basa. Nilai perbedaan warna yang ditunjukkan dari penodaan kain akibat pencucian menunjukkan kategori yang berbeda. Hasil ini menunjukkan bahwa zat warna reaktif dan azo memiliki kualitas seimbang dalam hal perubahan warna akibat keringat. Hasil pengujian juga menunjukkan bahwa tidak terdapat perbedaan nilai pada perubahan warna dalam dan katun terhadap sutera yaitu skala 4-5 atau sedikit lebih baik.

Hal ini nampak berbeda pada pengujian keringat terhadap zat golongan azo pada penggunaan konsentrasi $4,06 \%$ dan 4,07\%. Hasil uji keringat dengan $\mathrm{pH}$ asam menunjukkan nilai penodaan yang sama untuk sutera terhadap katun dan sutera terhadap wool yaitu pada skala 3-4 atau berkategori cukup baik. Namun pada penggunaan azo dengan konsentrasi $4,07 \%$ nilai penodaan warna hasil uji keringat dengan $\mathrm{pH}$ asam maupun $\mathrm{pH}$ basa nilainya pada skala 4 atau berkategori baik untuk semua sampel baik sutera terhadap katun maupun sutera terhadap wool.

Rentangan nilai toleransi perubahan warna dan penodaan warna zat reaktif dan azo pada pengujian keringat $\mathrm{pH}$ asam dan $\mathrm{pH}$ basa dijelaskan pada Tabel 5.

Tabel 5. Nilai Perubahan Warna dan Perbedaan Warna pada Uji Keringat

\begin{tabular}{|c|c|c|c|c|c|c|c|c|}
\hline \multirow{3}{*}{$\begin{array}{l}\text { Sampel } \\
\text { Uji }\end{array}$} & \multicolumn{4}{|c|}{ pH Asam } & \multicolumn{4}{|c|}{ pH Basa } \\
\hline & \multirow{2}{*}{$\begin{array}{l}\text { Perubahan } \\
\text { Warna } \\
\text { (C.D) }\end{array}$} & \multicolumn{3}{|c|}{ Perbedaan Warna (C.D) } & \multirow{2}{*}{$\begin{array}{l}\text { Perubahan } \\
\text { Warna } \\
\text { (C.D) }\end{array}$} & \multicolumn{3}{|c|}{ Perbedaan Warna (C.D) } \\
\hline & & Katun & Sutera & Wool & & Katun & Sutera & Wool \\
\hline$\overline{\text { Katun1 }}$ & 0,80 & 2,00 & 2,00 & - & 0,80 & 2,00 & 2,00 & - \\
\hline Katun2 & 0,80 & 2,00 & 2,00 & - & 0,80 & 2,00 & 2,00 & - \\
\hline Sutera1 & 0,80 & 5,60 & - & 5,60 & 0,80 & 5,60 & - & 5,60 \\
\hline Sutera2 & 0,80 & 4,00 & - & 4,00 & 0,80 & 4,00 & - & 4,00 \\
\hline
\end{tabular}

penggunaan zat reaktif menggunakan konsentrasi rendah maupun tinggi. Demikian pula untuk zat azo, tidak ada perbedaan nilai perubahan warna pada penggunaan zat azo menggunakan konsentrasi rendah maupun tinggi.

Perbedaan warna akibat keringat yang ditunjukkan dari skala penodaan memiliki nilai yang berbeda untuk masing-masing zat reaktif dan azo. Hasil uji keringat dengan $\mathrm{pH}$ asam pada zat reaktif menunjukkan nilai penodaan yang sama untuk katun terhadap katun dan katun terhadap sutera yaitu skala 4-5 atau berkategori sedikit lebih baik. Hasil uji keringat dengan $\mathrm{pH}$ basa juga menunjukkan nilai yang sama untuk katun terhadap katun
Tabel 5 menunjukkan bahwa kualitas zat warna reaktif dan azo tidak berbeda berdasar hasil pengujian keringat. Rentang perubahan warna yang terjadi diukur menggunakan nilai chromatic Adam menunjukkan hasil yang sama baik uji dengan $\mathrm{pH}$ asam maupun basa untuk sampel katun dan sutera, yaitu 0,80 C.D.

Sebaliknya, pada penggunaaan konsentrasi larutan berbeda, dyestuff jenis reaktif menghasilkan nilai perubahan warnanya lebih stabil jika dibandingkan dengan zat warna azo. Penggunaan konsentrasi rendah dan tinggi pada dyestuff jenis reaktif menghasilkan nilai 2,00 C.D. Pada dyestuff jenis azo, rentang nilai perbedaan warna dipengaruhi oleh konsen- 
trasi larutan yang digunakan. Penggunaan konsentrasi larutan tinggi menghasilkan nilai chromatic Adam yang lebih baik yaitu 4,0 C.D dan konsentrasi larutan rendah menghasilkan nilai 5,60 C.D. Hal tersebut menunjukkan bahwa konsentrasi larutan zat warna azo untuk pencelupan sutera memberi pengaruh pada kualitas penodaan warna yang dihasilkan.

\section{PEMBAHASAN}

Produk batik di Jawa Timur yang diproduksi oleh UKM dibuat menggunakan zat warna dengan jenis tertentu dan terbatas tergantung dari suplai (impor) yang ada sehingga ada batasan dalam hal kualitas hasil warnanya. Ketahanan luntur warna (colour fastness) merupakan parameter pada material produk pakaian yang menggambarkan performansi kinerja estetis dalam hal penampilan, disamping pengukuran kinerja mekanikal dan fisikal. Dalam 'siklus pakai' sebuah produk pakaian, kualitas warna kain yang kurang baik mengakibatkan penurunan secara progresif pada kualitas pakaian secara keseluruhan (Chakraborty, 2012). Usaha untuk memenuhi tuntutan kualitas produk pakaian memerlukan adanya kontrol pada hal-hal yang mempengaruhi hasil jadi atau color appearance (Vladic, 2014). Bide (135;2012) berpendapat bahwa menurunnya warna (color loss) berkaitan dengan daya tahan produk tekstil. Warna dapat berubah karena beberapa macam penyebab, dan warna pudar dapat terjadi akibat dari bahan pewarna yang rusak atau luruh.

Sesuai pendapat tersebut color loss dapat terjadi akibat dari penggunaan aktual (nyata) dan karena sebuah perlakuan tertentu. Salah satu aktifitas fisik yang berkaitan dengan produk pakaian adalah perawatan pencucian. Proses pencucian domestik melibatkan beberapa faktor yang berhubungan dengan kualitas warna. Beberapa faktor yang mempengaruhi hasil color loss pada proses pencucian antara lain: bahan kimia yang digunakan, ukuran dan konsentrasi celup, prosedur, interaksi bahan kimia selama proses, struktur material yang dicelup, dan formulasi deterjen yang digunakan (Chakraborty, 2008). Selain itu, gaya gesek yang terjadi pada material kain juga berpengaruh terhadap performansi, sehingga waktu, tekanan dan tarikan dalam selama proses pencucian akan berhubungan dengan kualitas warna. Secara keseluruhan aktivitas tersebut diukur menggunakan skala pengujian laboratorium dalam penilaian daya tahan warna yang dilakukan menggunakan sebuah perlakuan fisik tertentu menurut standar uji yang diacu. Hal ini tentunya untuk mendukung terpenuhinya persyaratan ekspor produk batik Jawa Timur sebagaimana tuntutan pasar global. Richard (2012) mengemukakan bahwa standar internasional untuk produk pakaian terkait ketahanan luntur warna kain, menuntut seleksi serta efisiensi metode pembuatannya yang harus di ukur sesuai standar uji yang berlaku, dan hal ini menjadi prasyarat dasar yang dituntut retailer dalam perdagangan.

Perubahan warna pada kain adalah terjadinya transfer warna dari obyek yang diwarnai. Pengukuran perubahan warna yang terjadi pada material tekstil dijelaskan melalui ketahanan luntur warna (colourfastness), sehingga pengujian tersebut selalu dilakukan untuk menentukan kualitas bahan tekstil. Kain uji disebut tidak tahan luntur apabila terjadi migrasi warna (bleeding) atau ada perubahan warna yang terjadi. Pada umumnya bleeding menyertai proses migrasi sehingga terjadi perubahan warna, meskipun bisa juga perubahan warna terjadi tanpa adanya bleeding. Prinsip pengujiannya menurut teori Trotman (1984) yaitu menilai perubahan warna pada kain uji (dye) dan kain putih tak berwarna (undye) dalam susunan tiga rangkai. 
Hasil pengujian juga menunjukkan bahwa zat warna jenis reaktif dan azo yang umumnya digunakan sebagai bahan baku batik di Jawa Timur memiliki kualitas warna yang berbeda. Dalam hal ini kualitas warna diukur dari daya tahan luntur warnanya. Sifat ketahanan luntur warna terhadap pencucian dan keringat yang diuji pada kain katun dan sutera menunjukkan nilai yang berbeda.

Identifikasi hasil pengujian tersebut menggambarkan perbedaan performansi kain katun dan sutera. Kain katun dan sutera memiliki performansi stabil untuk perubahan warna pada pengujian keringat, namun pada pengujian pencucian performansinya berbeda tergantung jenis zat warna yang digunakan, dan performansi pada hasil pengujian keringat dipengaruhi oleh konsentrasi larutan yang digunakan.

Kualitas tahan luntur warna terhadap pencucian yaitu menguji transfer warna dari kain berwarna hasil dari pencelupan menggunakan jenis dyestuff tertentu yang dibandingkan dengan kain sejenis yang tidak berwarna atau polos (tanpa dyeing) dan kain lain yang berbeda jenis seratnya dan/atau berbeda karakter. Hasil uji ketahanan luntur warna terhadap pencucian secara umum menunjukkan bahwa dalam hal perubahan warna yang terjadi, zat reaktif lebih baik dibandingkan dengan zat azo, namun dalam hal perbedaan warnanya hasil penodaan zat azo lebih baik dibandingkan dengan zat reaktif. Performansi tersebut terjadi karena zat reaktif yang diuji menggunakan bahan katun sebagai sampelnya. Hal ini sesuai dengan pernyataan Nikolaidas (2016) bahwa zat warna reaktif pada dasarnya merupakan hasil rekayasa terbaik dalam disain struktur molekul zat warna sintetis karena mampu memberikan kombinasi berbagai sifat unggul yang diinginkan, seperti corak warna lebih luas, lebih cerah, mudah rata, dan ketahanan luntur warnanya tinggi. Zat warna reaktif juga efektif diguna- kan pada jenis serat katun, wool dan campuran keduanya. Salah satu keunggulan penggunaan zat warna reaktif pada material katun adalah zat warna jenis reaktif ini memberi pengaruh terhadap ketahanan serat cotton terhadap sinar UV (Wai-YinWong, 2015).

Penggunaan konsentrasi larutan yang berbeda untuk zat reaktif pada kain katun tidak menunjukkan pengaruh pada nilai perubahan warna akibat pencucian. Ciri khas zat warna reaktif adalah kemampuannya dalam berikatan dengan serat tekstil untuk membentuk ikatan kovalen antara gugus reaktif dalam dyestuff tersebut dengan gugus $-\mathrm{OH},-\mathrm{SH},-\mathrm{NH}_{2}$, dan -NH yang ada dalam serat. Dalam proses dyeing reaksi hidrolisis juga terjadi disamping reaksi fiksasi sehingga efisiensi fiksasi berkurang (Karyana, 1998). Keterbatasan tersebut diperbarui pada jenis zat reaktif generasi baru yang memiliki kelebihan berupa efisiensi fiksasi lebih tinggi dan fiksasi dapat dilakukan pada suhu netral dan suhu tinggi sehingga dapat mengurangi pemakaian alkali dan elektrolit serta memiliki gugus lepas yang aman terhadap lingkungan. Karyana (1998) menyatakan bahwa melalui efek Donnan, $\mathrm{pH}$ dan penggunaan elektrolit berpengaruh terhadap substantivitas warna pada zat reaktif, dimana substantivitas mempengaruhi laju difusi zat warna reaktif. Hasil pengujian ini menunjukkan bahwa penggunaan konsentrasi larutan yang berbeda, namun proses pengerjaan dilakukan dengan menjaga suhu tetap stabil sesuai standar uji yang digunakan, tidak akan memberi efek terhadap nilai tahan luntur warna. Hal ini berarti bahwa bila koefisien difusi zat warna terjaga maka ketahanan lunturnya juga terjaga.

Performansi terbaik bahan katun tergantung dari metode pewarnaan yang digunakan. Metode baru untuk pewarnaan kain katun menurut Jia-Jie Long (2012) adalah pencelupan menggunakan vinysul- 
fone disperse dimana penyerapan carbon dioksida dan fiksasi katalis dilakukan dengan fase transfer catalyst Triethylene diamine (TEDA) dengan mengatur sistem temperatur dan tekanan.

Penggunaan jumlah pelarut dan larutan dengan perbandingan atau rasio yang berbeda pada zat azo juga tidak memberikan efek berbeda pada nilai perubahan warna. Namun demikian nilai perbedaan warna untuk penodaan pada kain dari serat wool menunjukkan adanya perbedaan yang signifikan. Hal tersebut terjadi karena serat wool merupakan serat protein yang tersusun dari asam amino- $\alpha$ dengan protein keratin sebagai struktur. Protein keratin mengandung cystin (disulphide linkage) dan garam yang menyebabkan serat wool menjadi stabil dan kuat (Dhende, 2012). Sebagai serat yang mengandung protein tinggi, kondisi tersebut bisa juga terjadi pada sutera, seperti yang disampaikan oleh Rebecca (2010) bahwa efek dari pencucian secara tidak langsung bisa berakibat pada warna dan konstruksi kain. Secara umum pencucian pada bahan sutera akan memberikan reaksi yang lebih tinggi pada faktor perubahan warna jika dibandingkan dengan perubahan yang terjadi pada faktor konstruksi kain.

Zat warna azo cenderung memiliki nilai penodaan warna yang berbeda jika dibandingkan dengan zat reaktif. Hasil pengujian warna sutera pada wool lebih baik dibandingkan dengan sutera pada katun. Perbedaan warna tersebut menunjukkan bahwa serat wool memiliki grade nilai lebih baik dibandingkan selulosa. Oleh sebab itu, jika zat azo dibandingkan dengan zat reaktif dapat dinyatakan bahwa kain berbasis serat protein menunjukkan performa lebih baik dibandingkan selulosa untuk ketahanan luntur terhadap pencucian. Performansi staining untuk zat azo tersebut dipengaruhi oleh proses pewarnaan yang kurang optimal. Menurut Lykidou (2016) dengan perlakuan fil- trasi berulang zat warna azo reaktif memiliki afinitas tinggi terhadap serat katun. Berdasar hal tersebut, UKM perlu meningkatkan kontrol pada proses pewarnaan bahan katun jika menggunakan zat azo sebagai dyestuf. Selain itu, proses pewarnaan pada bahan sutera akan lebih optimal jika dilakukan pada suhu tinggi. Hal ini terjadi karena kandungan sericin pada sutera lebih mudah larut dalam air bersuhu tinggi sehingga akan mengurangi nilai penodaan warna pada bahan sutera setelah pencucian (Nayeem, 2011).

Dalam hal perubahan warna yang terjadi hasil pengujian ketahanan luntur terhadap keringat, zat warna azo memiliki kualitas yang sama dengan zat warna reaktif. Hal ini karena tidak ditemukannya perbedaan warna pada masing-masing konsentrasi larutan yang diuji. Artinya adalah viskositas larutan yang rendah maupun tinggi tidak pada penggunaan zat reaktif dan azo tidak memberi efek terhadap hasil ketahanan luntur warna akibat keringat.

Penilaian perbedaan warna dari staining scale menunjukkan kategori yang bervariasi untuk masing-masing pengujian zat reaktif dan azo. Hasil perbedaan warna untuk kain katun lebih stabil dibandingkan dengan kain sutera. Penggunaan konsentrasi larutan yang berbeda untuk zat warna azo pada sutera menunjukkan nilai perbedaan warna yang tidak sama.

Konsentrasi rendah pada larutan yang digunakan untuk sutera pada katun dan sutera pada wool cenderung menghasilkan nilai penodaan yang lebih baik, sebaliknya pada konsentrasi tinggi dimana volume air pelarutnya lebih banyak menunjukkan tingkat penodaan warna yang kurang baik. Hal ini karena azo merupakan jenis zat warna yang sulit larut dalam air dan membutuhkan garam coupling untuk pembangkitan warnanya sehingga lebih efektif dalam larutan yang solid. 
Kecenderungan hasil penodaan yang berbeda tersebut bisa menjadi rekomendasi tersendiri bagi UKM yang menggunakan zat azo untuk bahan sutera supaya tidak menggunakan vlot rendah dalam proses pencelupan. Mengingat bahwa iklim di Indonesia yang cukup panas relatif menciptakan lingkungan yang dapat memicu tubuh untuk berkeringat lebih banyak, sehingga dampak tersebut dapat mempengaruhi kenyamanan yang pada akhirnya berkaitan dengan kualitas produk.

\section{SIMPULAN DAN SARAN}

Zat warna jenis reaktif pada bahan batik yang digunakan di Jawa Timur memiliki kualitas perubahan warna lebih baik dibandingkan penodaan warnanya untuk ketahanan luntur terhadap pencucian.

Konsentrasi larutan tidak memberikan efek nilai perubahan warna maupun penodaan, baik pada zat reaktif maupun azo yang digunakan selama penetapan suhu pencucian pada prosedur pengerjaan dijaga tetap stabil sesuai dengan standar yang digunakan.Penggunaan zat warna azo pada sutera-katun menghasilkan nilai penodaan yang lebih rentan dibandingkan sutera-wool.

Dalam hal ketahanan luntur terhadap keringat, zat warna reaktif dan azo jika digunakan pada material katun dan sutera memiliki kualitas perubahan warna yang sama baik pada pengujian keringat $\mathrm{pH}$ asam maupun $\mathrm{pH}$ basa.

Hasil penelitian ini menyarankan UKM batik yang menggunakan zat azo agar tidak menggunakan kain dari campuran sutera dan wool karena adanya sifat rentan dari penodaan warna yang akan terjadi akibat keringat, meskipun dalam hal ketahanan luntur terhadap pencucian baik. Zat warna azo sebaiknya digunakan dengan konsentrasi larutan yang kuat pada pencelupan sutera karena cen- derung menunjukkan nilai perbedaan warna yang lebih baik terhadap penodaan material jenis serat lain yaitu kapas dan wool, jika dibandingkan dengan konsentrasi larutan yang rendah.

\section{DAFTAR RUJUKAN}

Bide, M. 2012. Testing Textile Durability - in Understanding and Improving the Durability of Textiles, The Textile Institute, Woodhead Publishing Ltd.

Cegarra, J., Puente, P., \& Valldeperas, J. 1992. The Dyeing of Textiles Materials. Italy: Texilia.

Chakraborty, J.N. 2008. An Overview of Dye Fastness Testing, National Institute of Technology. Jalandhar, India.

Chakraborty, J.N. 2012. Strength Propeties of Fabrics:Understanding, Testing and Enhancing Fabric Strength. National Institute of Technology, Jalandhar, India.

Dhende, V.P., Hardin, I.R. \& Locklin, J. 2012. Durable Antimicrobial Textiles: Types, Finishes and Aplications, University of Georgia, USA.

Fan, Q. 2011. Fabric Chemical Testing. University of Massachusetts, USA.

ISO 105-A01. 2010. Textiles: Test for Colour Fatness, Part A01: General Principles of Testing.

ISO 105-E04. 2015. Textiles: Test for Colour Fastness. Part E04: Colour Fastness to Perspiration.

Isminingsih, J.R. 2013. Evaluasi Fisika Tekstil. Bandung: Sekolah Tinggi Teknologi Tekstil (STTT).

Jia-Jie L. Xiaoa, G.D., Xua, H.M., Wanga, L., Cuia, C.L., Liua, J., Yanga, M.Y., Wanga, K., Chena, C., Rena, Y.M., Luana, T., \& Dingb, Z.F. 2012. Dyeing of Cotton Fabric with a Reactive Disperse Dye in Supercritical Carbondioxide. Journal of Supercritical Fluids, 69: 13--20. 
Karyana, D. 1998. Struktur Zat Warna Reaktif dan Daya Celupnya. Sekolah Tinggi Teknologi Tekstil. Bandung. Lykidou, S., Tsatsaronie, E. 2016. Azo Reactive Dyes: Ultrafiltration and Apllication to Cotton. Textile Research Journal, 86(8): 823--836.

Nayeem, A., Faruqui, R.K., \& Sheikh. 2011. Effect of Modifications on Dyeing Behaviour and Tenacity of RajshahiSilk Fabric Dyed with Reactive Brown 10 and Direct Orange 31 Dyes. RJTA, 15(3): 1--6.

Nikolaous, N. 2016. Synthesis, Characterization, and Ultrafiltration of $\mathrm{Re}$ active Dyes. Textile Research Journal, 10: 1--14.

Phillips, D., Percival, R., Scotney, J., Bevan, G., \& Lloyd, J. 2003. Effect of Liquor Ratio on the Shade Change and Cross Staining Observed in the ISO 105-C08 Test. Coloration Technology, 119(3): 177--181.

Pindani, R.A. 30 September 2015. Batik Jawa Timur dan Tantanganya. Surabaya Pos, hal.1.

Raechel, M.L., Shani, E.G., \& Cheryl W. 2010. Standard Test Methode Adapted to Better Simulated Fabrics in Use, Textile Research Journal, 80(12): 1138--1150.
Rebecca, R., Amber, V., \& Brian, E.N. 2010. Effect of Laudering and Water Temperature on the Propertiesof Silk and Silk-Blend Knitted Fabric. Textile Research Journal, 88(15): $1557-$ $-1568$.

Richards, P.R. 2008, Methods of Dye Application. Colour Design: Theories and Applications, Woodhead Publishing Ltd, ISBN 978-1-84569972-7.

Trotman, E.R. 1984. Dyeing and Chemical Technology of Textiles Fibres, New York, John Wiley \& Sons.

Vladic, G. \& Novakovic, D. 2014. Color Appearence of Textile Materials Applied to Various Geometrical Shapes. Textile Research Journal, 84 (11): 1191--1199.

Wong, W.Y. \& Cheong, J.K. 2015. Influence of Reactive Dyes on Ultraviolet Proyection of Cotton Knitted Fabric with Different Fabric Construction. Textile Research Journal, 86(5): 512--532. 